Peshawar Journal of Psychology and Behavioral Sciences, 2015, Vol. 1, No. 2, 151-161

\title{
Parents Attitude Towards Enrollments in Public and Private Schools
}

\author{
Alamgeer Khan ${ }^{1}$, Hamad Ali ${ }^{2}$, Mushtaq Ahmad \\ Jadoon $^{3}$, Saima Sarir ${ }^{4}$, Intikhab Alam ${ }^{5}$ and \\ Muhammad Jawad 6 \\ The University of Agriculture, Peshawar Pakistan
}

Education not only enables us to become acceptable members of social sphere but also enable us to take right decision at right time. Parents' decision play important role in the lives of their children. The major aim of the present study was to find out the major causes of enrolling students in public schools by parents. Data for the study were collected from 280 respondents belonging to three selected villages in Tehsil Oghi, District Mansehra. The study found significant association between perception about enrollment in public schools and children's education was major priority of the educated parents, they understand their educational problems, teach them at home, give importance to sports, provides them latest technologies and facilities, provide tuition to children if needed, believed in hard work of parents and good grades of children in exams and ultimately educated parents' children obtain good grades. The study recommends that government should initiate mobilization campaign for illiterate parents, which will enhance the enrollment of children in public school.

Keywords. Education, children, public schools, parents, private schools and enrollments

The reputation of human assets of a nation can easily been determined from the number of educated people in a society. In other

${ }^{1}$ Lecturer, Department of Rural Sociology (AMK Campus Mardan), The University of Agriculture, Peshawar, Pakistan

2 Assistant professor, Department of Rural Sociology, The University of Agriculture, Peshawar, Pakistan

3 M.Phil. Scholar, Department of Rural Sociology, The University of Agriculture, Peshawar, Pakistan

${ }^{4}$ Lecturer, Department of Rural Sociology, University of Agriculture, Peshawar, Pakistan

${ }^{5}$ Lecturer, Department of Rural Sociology, The University of Agriculture, Peshawar, Pakistan

${ }^{6}$ Assistant professor, Department of Rural Sociology, The University of Agriculture, Peshawar, Pakistan 
words it can be thought that education is very much important and essential for a nation to endure progress, growth, advancement and much essential to sustain it in future days. The point may describe that nations with high education ratio and great human possessions are the most sardonic and advanced nations in the world (Goel, 2004). When seeing how developed a country is, you would measure how much communication, technology, industrialization, and urbanization is being used. Having social development in a country refers to health, laws, stability and social cohesion.

A healthy population is one that is filled with more educated women. Having educated women teachers helps to set good goals for girls as they were teaching. Highly educated women have smaller families because they know more about ways to control the family size. Education not only ameliorates a society morally, politically and culturally but also an abiding impact on an individual too. Education helps to shape people in the workforce that help to make our future national development better (Robert 1999). Educated parents involvement in students' education has been linked not only to higher achievement but also to increased academic motivation. Parenting style in general, like parental involvement, is shaped by background factors and context, as well as the unique values of each parent. Therefore, parenting behavior is different among different populations, and as parents express different values and behaviors, children's motivation is affected differently (Grolnick and Wendy 2009). Highly educated parents know the importance of education in the society and are more interested about the selection of school for their children bright future. Educated parents select the school with factors like better educational environment, quality education, and qualified staff and also are strictly managed by head. Empirical analysis reveals that, there is a positive relationship between parent's education and school selection.

Majority, of the parents would prefer to send their children to private school (Lankford and Wyckoff, 1992). Literate parents play a significant role in children educational progress. Because of education, the parents become primary teacher of their children at home and modest measureable efforts and revenues were enhanced by trials of teacher dimensions and dominance. School with small size classes and dissimilar student's bodies were not effective, whereas size of schools could not 
affect efficiency. Likewise, government school was more effective than private school but the educated parents always give preference to private schools because of quality education and ignore government school due to poor standard of education, which have bad impact on their performance (Kirjavainen and Loikkanent, 1998).

Educated parents also play a distinctive role in nourishment as well as in children's education too. Parents' education help them in children school selection and also provide opportunities for parents to enhance their parenting skills and life experiences to study further about children intellectual and progressive development. If parents are educated then it can take part at home during home visits as well as a cluster setting in family learning platform, whereas parents education happens in a crowd setting, it also support him in relationship with new parents for provision and association. Education is an imperative source for kinship to develop their abilities and make them confident to become a primary teacher for their children at home, and also make them viable to become complete partners in children education. Parents education is also essential for decision making of admitting their children either in public or private school (Tahir, 2005).

\section{Method}

The study was based on primary data, conducted in 2014. Those respondents which had at-least one child studying in public school and residing at any of the following three villages namely Khabal, Ismail Bandi and Ghanian of Tehsil Oghi District Mansehra Hazara division were the sampled respondents of the study. According to 1998 Population Censes report there were 1031 households in the selected villages data were collected from 280 sample respondents using Sekaran table.

\section{Conceptual Framework}

The following were the dependent and independent variables of the study.

Table 1

Peshawar Journal of Psychology and Behavioral Sciences, 2015, Vol. 1, No. 2, 151-161 
Conceptual Framework

\begin{tabular}{lc}
\hline Independent variable & Dependent Variable \\
\hline Parents' education & $\begin{array}{c}\text { Perception about children enrollment in } \\
\text { public schools }\end{array}$ \\
\hline
\end{tabular}

\section{Results and Discussion}

This section first describes the univariate and bivariate results. At univariate level it states the results regarding dependent variable i-e Perception about children enrollment in public schools and independent variable i-e parents' education. It is followed by the association between the two variables.

\section{Data Analysis}

After the collection of data, it were first coded and then entered in computer by using SPSS software for analysis. The analysis of the data was made at univariate and bivariate levels. The univariate analysis comprised of frequency distribution and percentages of the sampled respondents. Bivariate analysis was carried out to measure the association between dependent and independents variables. Chi-square and Fisher Exact tests were used to measure the association. The Chisquared test statistics for the test of independence summarizes how close the expected frequencies fall to the observed frequencies. It is represented by the symbol $x^{2}$. Karl Pearson introduced the statistics in 1900 and used in sociological studies to test the degree of independence (Tai, 1978). The formula used to compute Chi-square is given in the following:

$$
\chi^{2}=\sum_{i=1}^{r} \sum_{j=1}^{c} \frac{\left(O_{i j}-E_{i j}\right)^{2}}{E_{i j}}
$$

Where ${ }^{x^{2}}$ is chi-square, oij is observed frequencies in $i^{\text {th }}$ row and $\mathrm{j}^{\text {th }}$ column. Eij is expected frequencies in $\mathrm{i}^{\text {th }}$ row and $\mathrm{j}^{\text {th }}$ column whereas $\mathrm{r}$ is number or rows and $\mathrm{n}$ is number of column. The large summation sign, 
$\Sigma$ (capital sigma), tells us to compute the fractions for each cell and then sum over all cells to get ${ }^{x^{2}}$.

Fisher exact test was used when the frequencies in the table was less than 5. Following was the formula of the test.

Fisher Exact Test $=\frac{(a+b) !(c+d) !(a+c) !(b+d) !}{N ! a ! b ! c ! d !}$

Where $a, b, c$ and $d$ were the observed numbers in contingency table while " $n$ " were the total number of observations.

\section{Perception about Enrollments in Public Schools}

The major result of table 2 reveals that a total number of 53.2, $53.9,41.8,63.2,59.3,57.1,60.4,68.6,55.4$ and 72.5 percent of the sampled respondents reported agreed to the statements that public schools are the most suitable educational institutions, you prefer to enroll your children in private school than public schools, education in public school has been deteriorated from the last two decades, education in public schools is still good, public school is the only alternate option to give education to your children, you did not enroll any children in the public school, education in private school is better than the education in the public schools, the size of the student enrollment in public school is on decrease, education quality in public school is on decline, putting your children in public schools is the wastage of time and resources respectively.

Table 4

Perception about Enrollments in Public Schools (Dependent Variable)

\begin{tabular}{lccc}
\hline Statements & \multicolumn{1}{c}{ Yes } & No & Don't Know \\
\hline $\begin{array}{l}\text { Public schools are the most } \\
\text { suitable educational }\end{array}$ & $131(46.8)$ & $149(53.2)$ & $0(0)$ \\
institution. & & \\
You prefer to enroll your & $151(53.9)$ & $120(42.9)$ & $9(3.2)$ \\
children in private school \\
than public schools.
\end{tabular}




\begin{tabular}{|c|c|c|c|}
\hline $\begin{array}{l}\text { Education in public school } \\
\text { has been deteriorated from } \\
\text { the last two decades. }\end{array}$ & $117(41.8)$ & $140(50)$ & $23(8.2)$ \\
\hline $\begin{array}{l}\text { Education in public schools } \\
\text { is still good. }\end{array}$ & $177(63.2)$ & $86(30.7)$ & $17(6.1)$ \\
\hline $\begin{array}{l}\text { Public school is the only } \\
\text { alternate option to give } \\
\text { education to your children. }\end{array}$ & $166(59.3)$ & $103(36.8)$ & $11(3.9)$ \\
\hline $\begin{array}{l}\text { You did not enroll any } \\
\text { children in the public } \\
\text { school. }\end{array}$ & $160(57.1)$ & $111(39.6)$ & $5(1.8)$ \\
\hline $\begin{array}{l}\text { Education in private school } \\
\text { is better than the education } \\
\text { in the public schools. }\end{array}$ & $169(60.4)$ & $104(37.1)$ & $7(2.5)$ \\
\hline $\begin{array}{l}\text { The size of the student } \\
\text { enrollment in public school } \\
\text { is on decrease. }\end{array}$ & $192(68.6)$ & $82(29.3)$ & $6(2.1)$ \\
\hline $\begin{array}{l}\text { Education quality in public } \\
\text { school is on decline. }\end{array}$ & $155(55.4)$ & $121(43.2)$ & $4(1.4)$ \\
\hline $\begin{array}{l}\text { Putting your children in } \\
\text { public schools is the } \\
\text { wastage of time and } \\
\text { resources. }\end{array}$ & $57(20.4)$ & $203(72.5)$ & $20(7.1)$ \\
\hline
\end{tabular}

\section{Parents' Education}

Parent's education plays a vital role in making decision towards putting their children in a school or child labor. Major results of table 3 reveal that $69.6,72.9,75,67.9,66.1,50,71.1,65.4,42.9,46.1,61.1$ and 61.1 percent of the sample respondents (educated parents) were found agreed that children's education is their major priority, help the children in homework, understand their educational problems, teach their children at home, consider sports necessary, provide latest technologies and facilities to the children, not interacting with teacher, female education was also favored, give required time to their children's education, their children got good grades in examination, believe in hard work of parents and good grads of children and arrange tuitions for their children when needed respectively. 
From the above results it was concluded that children education was the major priority of parents. Moreover, the parent's education made them competent to teach their children at home and solve their educational problems. Table further reveals that children are not getting good grades in examination because of uneducated parents and majority of the parents had no interaction with their children teacher.

Table 3

Perception of the Sampled Respondents about Parents' Education

\begin{tabular}{|c|c|c|c|}
\hline Statements & Yes & No & Don't Know \\
\hline $\begin{array}{l}\text { Children education is your } \\
\text { major priority. }\end{array}$ & $195(69.6)$ & $83(29.6)$ & $2(.7)$ \\
\hline $\begin{array}{l}\text { You help your children in home } \\
\text { work }\end{array}$ & $204(72.9)$ & $75(26.8)$ & $1(.4)$ \\
\hline $\begin{array}{l}\text { Parent's education help to } \\
\text { understand the children } \\
\text { educational problems. }\end{array}$ & $210(75.0)$ & $69(24.6)$ & $1(.4)$ \\
\hline $\begin{array}{l}\text { Your education will enable you } \\
\text { to teach your children at home. }\end{array}$ & $190(67.9)$ & $85(30.4)$ & $4(1.4)$ \\
\hline $\begin{array}{l}\text { You think sports as a } \\
\text { requirement of children's } \\
\text { education. }\end{array}$ & $185(66.1)$ & $88(31.4)$ & $7(2.5)$ \\
\hline $\begin{array}{l}\text { You provide latest technologies } \\
\text { and facilities to your children. }\end{array}$ & $140(50.0)$ & $132(47.1)$ & $8(2.9)$ \\
\hline $\begin{array}{l}\text { You are not interacting with } \\
\text { your children's teacher. }\end{array}$ & $199(71.1)$ & $77(27.5)$ & $4(1.4)$ \\
\hline $\begin{array}{l}\text { You are in favor of female } \\
\text { education. }\end{array}$ & $183(65.4)$ & $91(32.4)$ & $6(2.1)$ \\
\hline $\begin{array}{l}\text { You give full time to your } \\
\text { children education. }\end{array}$ & $120(42.9)$ & $144(51.4)$ & $16(5.7)$ \\
\hline $\begin{array}{l}\text { Your children get good grades } \\
\text { in examination. }\end{array}$ & $129(46.1)$ & $149(53.2)$ & $2(.7)$ \\
\hline $\begin{array}{l}\text { Good grades are due to hard } \\
\text { work by parents. }\end{array}$ & $171(61.1)$ & $103(38.8)$ & $3(1.1)$ \\
\hline $\begin{array}{l}\text { You have arranged tuitions for } \\
\text { your children if necessary. }\end{array}$ & $185(66.1)$ & $91(32.5)$ & $4(1.4)$ \\
\hline
\end{tabular}




\section{Parent's Education and Perception about Enrollment in Public Schools}

Table 4 provides information on the association between perception about enrollments in public schools and parent's education. Those found significant include children education is your major priority $(P=00.02)$, parents education help to understand the children educational problems ( $P=0.074)$, parent's education enable them to teach their children at home $(P=0.031)$, sports as a requirement of children's education $(p=0.059)$, they provide latest technologies and facilities to their children ( $p=0.040)$, educated parent's children get good grades in examination, $(p=0.000)$. good grades are due to hard work by parents $(p=0.053$ ), they arranged tuitions for children if necessary $(\mathrm{p}=0.017)$. Those found insignificant include they help their children in home work ( $p=0.138)$, they have interaction with children's teacher ( $P=0.169)$, they were in favor of female education $(p=0.125)$ and give full time to their children education was also found nonsignificant $(p=0.104)$ with perception about enrollments in public schools and parents education.

From the above table it was concluded that parents' education not only made children education as their major priority but also they taught their children at home, providing technologies and facilities and consequently their children get good grades in examination.

Table 4

Association between Parents education and Perception about Enrollments in Public schools

\begin{tabular}{lllllll}
\hline Statement & Respo & \multicolumn{3}{c}{ Enrolment Public schools } & Total & Statistic \\
\cline { 3 - 6 } & nse & Yes & No & $\begin{array}{l}\text { Don't } \\
\text { know }\end{array}$ \\
\hline Children & Yes & $115(71.0)$ & $69(65.1)$ & $11(91.7)$ & $195(69.6)$ & $x^{\mathbf{2}}=16.426$ \\
education is & No & $47(29.0)$ & $36(34.0)$ & $0(0)$ & $83(29.6)$ & $(\mathbb{P}=00.02)$ \\
$\begin{array}{l}\text { your major } \\
\text { priority. }\end{array}$ & Don't & $0(0)$ & $1(0.9)$ & $1(8.3)$ & $2(0.7)$ & \\
\hline
\end{tabular}




\begin{tabular}{|c|c|c|c|c|c|c|}
\hline \multirow{3}{*}{$\begin{array}{l}\text { You help } \\
\text { your } \\
\text { children in } \\
\text { home work. }\end{array}$} & Yes & $125(77.2)$ & $73(68.9)$ & $6(50.0)$ & $204(72.9)$ & $x^{2}=6060$ \\
\hline & No & $37(22.8)$ & $32(30.2)$ & $6(50.0)$ & $75(26.8)$ & $(P=0.138)$ \\
\hline & $\begin{array}{l}\text { Don't } \\
\text { know }\end{array}$ & $0(0.0)$ & $1(0.9)$ & $0(0.0)$ & $1(0.4)$ & \\
\hline \multirow{3}{*}{$\begin{array}{l}\text { Parent's } \\
\text { education } \\
\text { help to } \\
\text { understand } \\
\text { the children } \\
\text { educational } \\
\text { problems. }\end{array}$} & Yes & $126(77.8)$ & $72(67.9)$ & $12(100)$ & $210(75.0)$ & $x^{2}=8.543$ \\
\hline & No & $35(21.6)$ & $34(32.1)$ & $0(0.0)$ & $69(24.6)$ & $p=0.074)$ \\
\hline & $\begin{array}{l}\text { Don't } \\
\text { know }\end{array}$ & $1(0.6)$ & $0(0.0)$ & $0(0.0)$ & $1(0.4)$ & \\
\hline \multirow{3}{*}{$\begin{array}{l}\text { Your } \\
\text { education } \\
\text { will enable } \\
\text { you to teach } \\
\text { your } \\
\text { children at } \\
\text { home. }\end{array}$} & Yes & $101(62.3)$ & $82(77.4)$ & $7(58.3)$ & $190(67.9)$ & $x^{2}=13.895$ \\
\hline & No & $58(35.8)$ & $23(21.7)$ & $4(33.3)$ & $85(30.4)$ & $(p=0.031)$ \\
\hline & $\begin{array}{l}\text { Don't } \\
\text { know }\end{array}$ & $3(1.9)$ & $0(0.0)$ & $1(8.3)$ & $4(1.4)$ & \\
\hline \multirow{3}{*}{$\begin{array}{l}\text { You think } \\
\text { sports as a } \\
\text { requirement } \\
\text { of } \\
\text { children's } \\
\text { education. }\end{array}$} & Yes & $114(70.4)$ & $61(57.5)$ & $10(83.3)$ & $' 85(66.1)$ & $x^{2}=9.100$ \\
\hline & No & $45(27.8)$ & $42(39.6)$ & $1(8.3)$ & $88(31.4)$ & $(P=0.059)$ \\
\hline & $\begin{array}{l}\text { Don't } \\
\text { know }\end{array}$ & $3(1.9)$ & $3(2.8)$ & $1(8.3)$ & $7(2.5)$ & \\
\hline \multirow{3}{*}{$\begin{array}{l}\text { You } \\
\text { provide } \\
\text { latest } \\
\text { technologie }\end{array}$} & Yes & $79(48.8)$ & $55(51.9)$ & $6(50.0)$ & $140(50.0)$ & $x^{2}=10.043$ \\
\hline & No & $78(48.1)$ & $50(47.2)$ & $4(33.3)$ & $132(47.1)$ & $(P=0.040)$ \\
\hline & $\begin{array}{l}\text { Don't } \\
\text { know }\end{array}$ & $5(3.1)$ & $1(0.9)$ & $2(16.7)$ & $8(2.9)$ & \\
\hline $\begin{array}{l}\text { facilities to } \\
\text { your } \\
\text { children. }\end{array}$ & & & & & & \\
\hline \multirow{3}{*}{$\begin{array}{l}\text { You are not } \\
\text { interacting } \\
\text { with your } \\
\text { children's } \\
\text { teacher. }\end{array}$} & Yes & $117(72.2)$ & $75(70.8)$ & $7(58.3)$ & $199(71.1)$ & $x^{2}=6.440$ \\
\hline & No & $42(25.9)$ & $31(29.2)$ & $4(33.3)$ & $77(27.5)$ & $(p=0.169)$ \\
\hline & $\begin{array}{l}\text { Don't } \\
\text { know }\end{array}$ & $3(1.9)$ & $0(0.0)$ & $1(8.3)$ & $4(1.4)$ & \\
\hline \multirow{3}{*}{$\begin{array}{l}\text { You are in } \\
\text { favor of } \\
\text { female } \\
\text { education. }\end{array}$} & Yes & $110(67.9)$ & $63(59.4)$ & $10(83.3)$ & $183(65.4)$ & $x^{2}=7.220$ \\
\hline & No & $49(30.2)$ & $41(38.7)$ & $1(8.3)$ & $91(32.5)$ & $(p=0.125)$ \\
\hline & $\begin{array}{l}\text { Don't } \\
\text { know }\end{array}$ & $3(1.9)$ & $2(1.9)$ & $1(8.3)$ & $6(2.1)$ & \\
\hline You give & Yes & $62(38.3)$ & $54(50.9)$ & $7(58.3)$ & $120(42.9)$ & $x^{2}=7.689$ \\
\hline
\end{tabular}

Peshawar Journal of Psychology and Behavioral Sciences, 2015, Vol. 1, No. 2, 151-161 


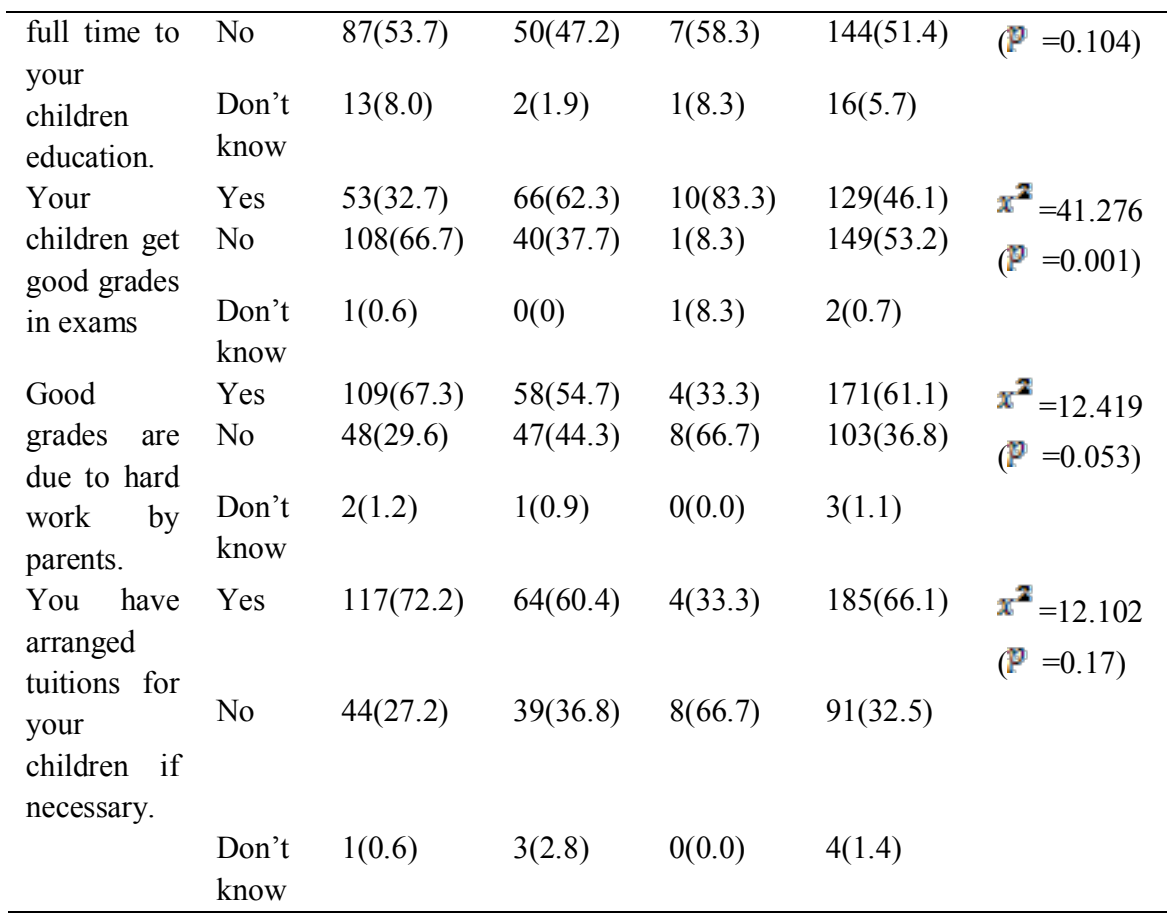

\section{Conclusion and Recommendations}

Educated parents know the importance of education and in not ready to compromise at any level on their children's education. The study also finds significant association concerning education as a major priority of educated parents, understands their educational problems, teaches them in home, gives importance to sports, provides them latest technologies / facilities, arrange tuition for children if needed, believed that the good grades of children is due to hard work of parents which in return bring good grades to children in examination.

On the bases of findings of study it is recommended that government should launch mobilization campaigns to motivate the illiterate parents to enroll their children as the educated parents are already anxious about children's education. Furthermore adult education should be made mandatory for illiterate adults this will increase the number of children enrollment in schools. Children are the best change agents, lessons and stories should be included in curriculum so that they can convince the 
illiterate parents of their peer groups to enroll their children which will ultimately increase the enrollment of children in schools

\section{References}

Goel, A. 2004. Education and socio-economic perspectives of women development and empowerment. Deep \& Deep Publications Pvt. Ltd., New Delhi.

Govt. of Pakistan. 1998. Census Report of District Mahnsara, Hazara Division, 1998. Population Census Organization, Statistics Division, Islamabad, Pakistan.

Grolnick, W. S. (2009). The role of parents in facilitating autonomous self-regulation for education. Theory and Research in Education, 7(2), 164-173.

Lankford, R. H., and J.H, Wyckoff. 1992. "Primary and secondary school choice among public and religious alternatives". Economics of Education Review, 11, 317-337 Paulina 2000.

Kirjavainena.T, and Loikkanent 1998. "Efficiency differences of finish senior secondary schools an application of DEA and Tobit analysis". Economics of Education Review.17 (4): 377-394. http://www.sciencedirect.com/science?_ob=ArticleURL\&_udi=B6 VB9-

Tahir, H. 2008. A Comparative study of school culture of public and private schools in Lahore District. Unpublished Thesis of Master in Education. Division of Education, University of Education, Lahore.

Tai, S.W. (1978). Social Science Statistics: Its Elements and Application. California, Goodyear Publishing Company.

Sekaran (2003), Research method for business. Hermitage public series, USA. 